\title{
Molecular Diversity of Arbuscular Mycorrhizal Fungi (AMF) Associated with Carissa edulis, an Endangered Plant Species along Lake Victoria Basin of Kenya
}

\author{
Benard O. Ogoma $\mathbb{D}^{\mathbb{D}},{ }^{1}$ Stephen F. Omondi $\mathbb{D}^{2}{ }^{2} \mathrm{Jane}$ Ngaira, ${ }^{1}$ and Josephine W. Kimani ${ }^{1}$ \\ ${ }^{1}$ Jomo Kenyatta University of Agriculture and Technology, P.O Box 6200-00200, Nairobi, Kenya \\ ${ }^{2}$ Kenya Forestry Research Institute, P.O Box 20412-00200, Nairobi, Kenya \\ Correspondence should be addressed to Benard O. Ogoma; benkogoma@yahoo.com
}

Received 21 April 2021; Accepted 17 August 2021; Published 27 August 2021

Academic Editor: MANOJ Kumar Solanki

Copyright (c) 2021 Benard O. Ogoma et al. This is an open access article distributed under the Creative Commons Attribution License, which permits unrestricted use, distribution, and reproduction in any medium, provided the original work is properly cited.

\begin{abstract}
Carissa edulis is a tropical plant belonging to the family Apocynaceae. The species is widely used in the preparation of various herbal medicines. Earlier works in Kenya show that an aqueous extract from the roots of $C$. edulis has remarkable anti-herpes simplex virus. Due to its medicinal value, the species has been overexploited in its natural range and requires conservation interventions. Studies show that the species has beneficial relationships with arbuscular mycorrhizal fungi (AMF) that can enhance restoration of its population; however, no study has been undertaken to document the diversity of these AMF species. This study evaluated the genetic diversity of AMF associated with the roots of $C$. edulis within Lake Victoria basin ecosystem of Kenya. A cross-sectional, laboratorybased prospective study was carried out from roots of $C$. edulis collected from six sites within the ecosystem. Root samples were collected from 6 points (replicates) per site. AMF was assessed through morphological characterization and sequencing of small subunit of ribosomal DNA. Morphological identification identified four genera of AMF (Gigaspora, Acaulospora, Scutellospora, and Glomus) with no significant difference among the sites. Molecular analysis also revealed presence of four genera, but only two (Glomus and Acaulospora) were common for both the analyses with Glomus as the most predominant genera. In all the sites, there were large numbers of spores both in soil and in the roots confirming the association between C. edulis and AMF.
\end{abstract}

\section{Introduction}

Carissa edulis is a spiny evergreen shrub or tree having grey bark, with straight woody spines of about $5 \mathrm{~cm}$, often in pairs. Leaves are opposite, leathery, shiny dark green approximately $5 \mathrm{~cm}$ with pointed tip and rounded base. The flowers are fragrant in pink-white terminal clusters. The berries are round approximately $1 \mathrm{~cm}$ and purple-black when ripe. Carissa edulis is widespread in many parts of Africa [1]. The species grows at forest edges, in forests and woodlands where Euphorbia, Acacia, and Croton commonly occur, especially on rocky hillsides, on clay soils, mainly black cotton soils, in dry and moist low and midlands of 1500-2500 $\mathrm{m}$ [1]. The species was once common across Lake Victoria basin ecosystem; however, its distribution is currently dwindling due to overexploitation. East African communities commonly use C. edulis as herbal medicine in different ways. Traditionally, decoctions of C. edulis roots are used as antimalaria and painkiller, and powdered roots are used to treat chest pain, while infusion from roots is used to relieve stomachache [2].

In Kenya, a study by Kenya Medical Research Institute (KEMRI) has shown that an aqueous extract from the roots of C. edulis has remarkable anti-herpes simplex virus (HSV) which is a major opportunistic infection in immunocompromised persons [3]. Herpes simplex virus is a serious threat in HIV/AIDS prone areas in sub-Saharan Africa. As such, C. edulis is highly sought for its medicinal value in East Africa and Africa as a whole. This has led to indiscriminate overexploitation of the species, together with other factors such as deforestation and climate change which has resulted in habitat loss, thereby leaving only patches of C. edulis 
available across the region. There is therefore the need to develop management strategies for the species conservation including restocking and promotion of on-farm cultivation for sustainable herbal medicine utilization. To achieve this, however, knowledge of both bellow and above ground association with other organisms is imperative. Carissa edulis is believed to have beneficial relationships with some arbuscular mycorrhizal fungi (AMF). However, no studies have been undertaken on the species to document the AMF association within Lake Victoria basin ecosystem to support conservation strategies within the region.

Mycorrhizae are mutualisms formed between fungi and plant roots [4]. The most studied types of mycorrhizae are arbuscular mycorrhizae, ericoid mycorrhizae, arbutoid mycorrhizae, and orchid mycorrhizae. Generally, arbuscular mycorrhizal fungi are very important in land reclamation and functions in sustaining soil fertility and recycling nutrients that increases plant nutrients supply through acquisition of nutrient such as phosphorus and nitrogen that would not be available to plants thus increasing the plant growth vigour [5]. A study in the Coastal region of Eastern Madagascar has linked C. edulis with AMF [6]. Colonization of roots by mycorrhizal fungi also benefits the host plant by improving water uptake. In exchange, the host plant provides the mycorrhizal fungi with carbon from photosynthesis for its energy requirement [7]. It is estimated that $80 \%$ of plant species are associated with mycorrhizal fungi, $67 \%$ of which is AMF, which may differ in their growth response to a variety of plant species [8]. Thus, the presence or absence of particular AMF species, and overall diversity, can affect the productivity and diversity of host plant communities, both in experimental greenhouse studies and in natural ecosystems $[8,9]$. In other instances, species-specific fungal pathogens may promote dominance of one species by limiting recruitment of conspecific species near parent plants thus providing opportunities for only some species to grow [10]. To successfully implement any planting program for the species that has association with AMF, it is important to understand the species growth mechanisms and requirements including below ground associations with beneficial microorganisms. The main objective of the present study was to determine the genetic diversity of AMF found in association with the roots of C. edulis growing within Lake Victoria region of Kenya. To achieve this, both morphological characteristics of AMF and molecular analysis of small subunit of rDNA were employed.

\section{Materials and Methods}

2.1. Study Area. The study was conducted in Homa Bay (Kendu Bay and Gembe hills), Kisumu (Seme and Nyahera), and Siaya (Got Ramogi and Nyabeda) counties along Lake Victoria basin of Kenya where C. edulis is found (Figure 1). Lake Victoria ecosystem is found in the South Western part of Kenya. The ecosystem has warm, dry, and humid climate with mean annual rainfall ranging within $800-1600 \mathrm{~mm}$. It covers an area of about $4100 \mathrm{~km}^{2}$. The region is rich in biodiversity with different plant species, some of which have medicinal value. Carissa edulis is one of the species found in this region which is most sought for because of its medicinal value. The communities that live in this region rely on C. edulis among other traditional medicinal plants for their local ailments, hence the need for increased productivity of the plant and conservation where its population is threatened.

2.2. Field Sample Collection. We collected fine root samples of $C$. edulis trees selected randomly where the species is found. From each site, five replicates of single standing C. edulis trees separated by at least $100 \mathrm{~m}$ were randomly selected and roots collected. Fine roots from each tree were excavated from at least three lateral roots starting from the trunk and working out towards the fine roots. The roots selected for harvesting were located at different directions from the stem, at least $90^{\circ}$ from each other. After harvesting, roots were packed in khaki bags and transported to the laboratory. The roots were rinsed in running tap water to remove attached soil and debris. The samples were cut into pieces of about $1 \mathrm{~cm}$ and stored in 70\% alcohol until subsequent analysis. Composite soil samples of 3 replicates were also collected under the canopy of the tree from where fine roots were collected. The soil samples were collected from two different depths, within $0-15 \mathrm{~cm}$ and $15-30 \mathrm{~cm}$. The soil samples were placed in khaki papers, labelled, and transported to the laboratory for fungal spore characterization.

2.3. Preliminary Spore Isolation and Count. Preliminary spore isolation from the soil samples was done by wet sieving as described in [11] and spore count done using a $\times 50$ dissecting microscope. The number of spores was recorded per sample.

2.4. AM Fungal Trap Culture (Bulking). After preliminary spore count, soil samples were mixed with autoclaved, medium-sized sand in the ratio of $1: 4$. The samples were packed in one-litre plastic pots in a glasshouse. Sorghum was sown as a trap plant at a density of fifteen seeds per pot. After seedling germination, pots were watered once a day to keep $60 \%$ of water-holding capacity (WHC). The pot culture experiment ran for 3 months. Two weeks prior to harvesting, the sorghum was subjected to water stress to enhance sporulation of the existing AMF species. The water stress was ensured by watering the sorghum twice a week instead of everyday.

2.5. Spore Isolation and Morphological Characterization. Pot cultures were harvested from the glass house and AMF spores isolated by wet-sieving technique as described in [11]. Withered sorghum was uprooted, soil thoroughly homogenized, and approximately $50 \mathrm{~g}$ from each pot collected for spore isolation. The soil samples were soaked in $200 \mathrm{ml}$ of water and sieved through 45- and 65-micron sieves. Debris from the 65 microns sieve was transferred into falcon tubes and mixed with sucrose solution (48\%). The mixture was shaken and left to stand overnight. The debris was sieved through a 65-micron sieve, cleaned, and observed under microscope. Spores were counted and characterized according to their sizes, colour, shape, and presence of 


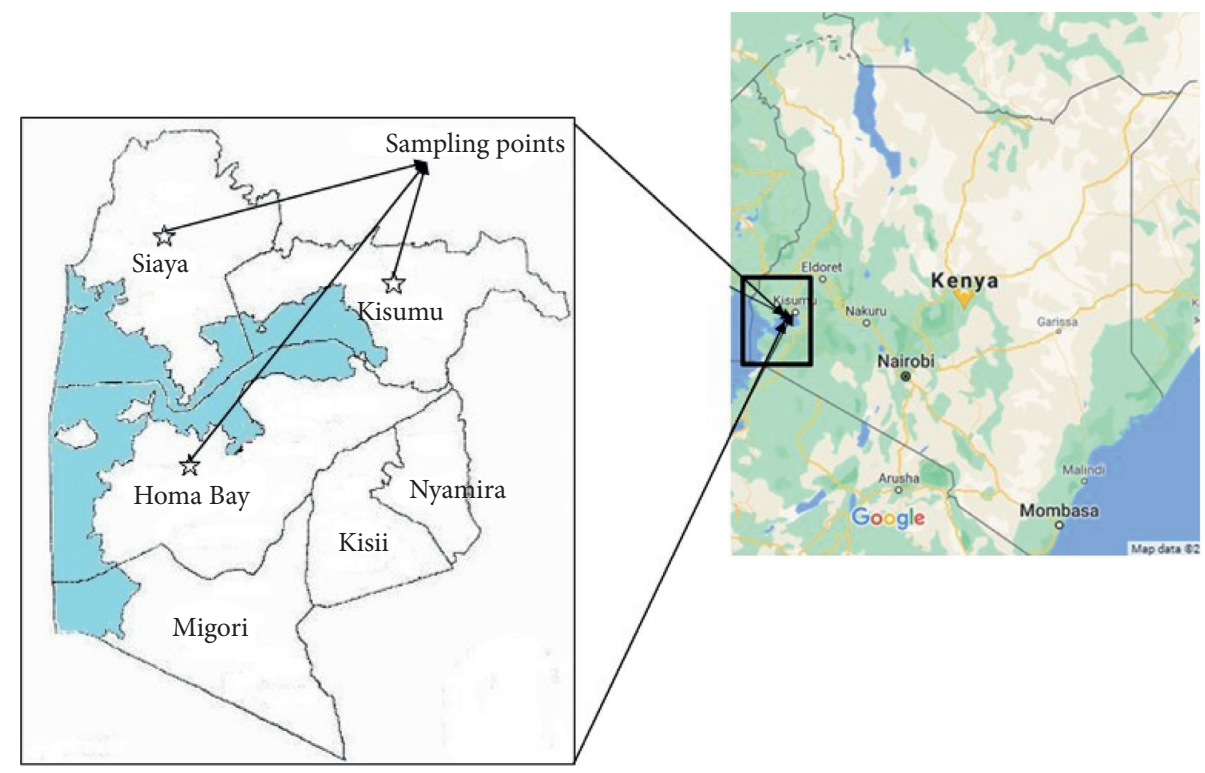

Figure 1: Map showing the study sites where C. edulis were sampled.

subtending hyphae. Spores less than $120 \mu \mathrm{m}$ were classified as small whereas those greater than $120 \mu \mathrm{m}$ were regarded as large [12]. Some spores were fished using a spore sucker after successful identification for examination under $\times 50$ fluorescent microscope.

2.6. Root Examination for Spore Percentage Infection. Roots were examined for spore percentage infection using $\times 50$ dissecting microscope. The examined roots were subjected to bleaching in $10 \%(w: v) \mathrm{KOH}$ and stained in $0.05 \%$ trypan blue [13]. Root colonization was quantified using the gridline-intersect method [14].

2.7. DNA Isolation and Polymerase Chain Reaction (PCR). Fine roots of $C$. edulis were gathered in Eppendorf tubes, airdried, and then ground into powder using a mixer mill (MM 300, Retsch, Haan, Germany). DNA was extracted using modified cetyl trimethyl ammonium bromide (CTAB) method described in [15]. Ground plant tissues were transferred to a $2.0 \mathrm{ml}$ microfuge tube containing $500 \mu \mathrm{l}$ isolation buffer (IB) and mixed by vortexing. The mixture was then centrifuged at $10,000 \mathrm{rpm}$ at $4^{\circ} \mathrm{C}$ for $3 \mathrm{~min}$. Supernatant was removed and $800 \mu \mathrm{l}$ of fresh IB was added and then vortexed. CTAB (2\% CTAB, $20 \mathrm{mM}$ EDTA, $100 \mathrm{mM}$ Tris- $\mathrm{HCl}, \mathrm{pH} 8.0,1.4 \mathrm{M} \mathrm{NaCl}$, and $0.2 \% \beta$-mercaptoethanol) solution $(800 \mu \mathrm{l})$ was added to the mixture and incubated at $65^{\circ} \mathrm{C}$ for $40 \mathrm{~min}$ and then incubated again at $37^{\circ} \mathrm{C}$ for another $40 \mathrm{~min}$. Chloroform isoamyl alcohol (CIA) $(800 \mu \mathrm{l})$ was added and mixed by inversion for $10 \mathrm{~min}$. Upper aqueous was transferred to a new $2.0 \mu \mathrm{l}$ microfuge tube. An equal volume of CIA was added and mixed by inversion for $10 \mathrm{~min}$. The mixture was again centrifuged at $14000 \mathrm{rpm}$ for $10 \mathrm{~min}$ at room temperature. Upper aqueous was transferred to a new $1.5 \mathrm{ml}$ microfuge tube and then $1 / 10$ volume of $3 \mathrm{M}$ $\mathrm{NaOAc}$ was added. An equal volume of isopropanol was added and mixed by inversion. The mixture was centrifuged at $15,000 \mathrm{rpm}$ at $4^{\circ} \mathrm{C}$ for $5 \mathrm{~min}$. The supernatants were discarded and then $800 \mu \mathrm{l} 70 \%$ ethanol was added and flipped to wash the DNA. It was centrifuged at $15,000 \mathrm{rpm}$ at $4^{\circ} \mathrm{C}$ for $5 \mathrm{~min}$ to pellet the DNA. Supernatant was discarded and DNA pellet was air-dried. The DNA pellet was dissolved using DNase-free water $(100 \mu \mathrm{l})$ in readiness for PCR analysis.

2.8. Nested Polymerase Chain Reaction Analysis. Partial small subunit rDNA fragments were amplified using nested PCR [16] with the universal eukaryotic primers NS1 and NS4 and a subsequent amplification round with the glomeromycotaspecific primers AML1 and AML2 (Table 1). PCR was carried out using $0.5 \mu \mathrm{l}$ of $10 \mathrm{x}$ dNTPs, $1.0 \mu \mathrm{M}$ of each primer, $5 \mathrm{U}$ of Taq DNA polymerase, $1.0 \mu$ of $10 \mathrm{x}$ buffer, $0.5 \mu \mathrm{l}$ of $25 \mathrm{x}$ $\mathrm{Mgcl}_{2}, 0.5 \mu \mathrm{l}$ of $25 \% \mathrm{PVP}$, and $0.5 \mu \mathrm{l}$ of $10 \mathrm{mg} / \mathrm{ml} \mathrm{BSA}$ in total volume of $10.5 \mu \mathrm{l}$. The PCR programme was as follows: initial denaturation at $95^{\circ} \mathrm{C}$ for $3 \mathrm{~min}$, followed by 35 cycles at $95^{\circ} \mathrm{C}$ for $30 \mathrm{~s}, 58^{\circ} \mathrm{C}$ for $1 \mathrm{~min}, 72^{\circ} \mathrm{C}$ for $1 \mathrm{~min}$, followed by a final extension period at $72^{\circ} \mathrm{C}$ for $10 \mathrm{~min}$. A $2 \mu \mathrm{l}$ aliquot of each PCR product was analyzed in electrophoresis using a $1.5 \%$ agarose gel stained in SYBR safe $\left(0.5 \mu \mathrm{g} \mathrm{ml}^{-1}\right)$ and photographed under UV light. The first PCR products were used as template DNA in a second PCR. The second reaction was performed using AMF specific primers, AML1 and AML2. The following PCR programme was used: initial denaturation at $95^{\circ} \mathrm{C}$ for $3 \mathrm{~min}$, followed by 35 cycles of $30 \mathrm{~s}$ denaturation at $95^{\circ} \mathrm{C}, 1$ min primer annealing at $58^{\circ} \mathrm{C}$, and 1 min extension at $72^{\circ} \mathrm{C}$, followed by a final extension period of $10 \mathrm{~min}$ at $72^{\circ} \mathrm{C}$. The nested PCR products were then subjected to restriction fragment length polymorphism (RFLP) using restriction enzymes.

2.9. Restriction Fragment Length Polymorphism (RFLP). The gel electrophoresis method used was as performed in $[19,20]$ to confirm the amplification of the target region. 
TABLE 1: Primer sequences used in nested PCR amplification of AMF.

\begin{tabular}{lcccc}
\hline Gene & Primer name & Primer sequence $\left(5^{\prime}-3^{\prime}\right)$ & Bp sizes & Reference \\
\hline \multirow{2}{*}{ SSU } & NS1 & GTAGTCATATGCTTGTCTC & 1200 & 1200 \\
& NS4 & CTTCCGTCAATTCCTTTAAG & White et al. [17] \\
\hline \multirow{2}{*}{ SSU } & AML1 & ATCAACTTTCGATGGTAGGATAGA & 800 & Lee et al. [18] \\
& AML2 & GAACCCAAACACTTTGGTTTCC & 800 & \\
\hline
\end{tabular}

Four restriction enzymes used to digest nested PCR products previously amplified by specific primers AML1 and AML2 were HaeIII, MpsI, Hinfl, and HhaI. Each of the 21 samples that were amplified for $18 \mathrm{~s}$ rDNA was divided into 4 Eppendorf tubes and labelled indicating the name of the enzyme. In each tube, $6 \mu \mathrm{l}$ PCR products, $2.6 \mu \mathrm{l} \mathrm{H}_{2} \mathrm{O}, 1 \mu \mathrm{l}$ buffer, $0.1 \mu \mathrm{l}$ BSA were added, after which each enzyme was added to its respective labelled tube. The reaction tube was incubated at $37^{\circ} \mathrm{C}$ for four hours. Amplified fragments were separated using 1.5\% agarose gel electrophoresis for $70 \mathrm{mins}$. The gel was stained by adding $3.5 \mu \mathrm{l} \mathrm{SYBR}$ Safe dye (Invitrogen $10,000 \mathrm{x}$ concentrate in DMSO) and molten in a microwave oven for $1 \mathrm{~min}$. The digested products were then mixed with $1 \mathrm{x}$ gel loading dye (Thermo Scientific) and $2 \mu \mathrm{l}$ of the products was loaded into the gel. $100 \mathrm{bp}$ Plus DNA ladder (Thermo Scientific) was used for sizing the fragments. The gels were viewed and documented using UV illumination (ATTA E-Graph).

2.10. Sequencing Arbuscular Mycorrhizal Fungi DNA. Nested PCR products were used for BigDye Sanger Sequencing where PCR amplicons were electrophoresed on a $2 \%$ agarose gel (Sigma-Aldrich Co., USA) stained in $2 \mu \mathrm{g} / \mathrm{ml}$ ethidium bromide (Sigma-Aldrich Co., USA) solution and visualized using the E-box gel documentation system (Vilber Lourmat, France). The amplicons were subsequently purified using Exonuclease I/Shrimp Alkaline Phosphatase (ExoSap-IT) enzyme (Affymetrix, USA) following the manufactures' guidelines. The amplicons were sequenced on both strands on an automated 3500xL Genetic Analyzer (Applied Biosystems, USA) using the same primers that were used for amplification. Cycle sequencing was performed using the BigDye Terminator Cycle sequencing kit v3.1 (Applied Biosystems, USA).

2.11. Statistical Analysis. The data were subjected to analysis of variance (ANOVA). The means were compared using $t$ test whereby the mean of the study was compared to the known existing means $[21,22]$ and was found to be statistically significant with $P$ value $<0.05$. Sequence editing was done using Sequencher V4.2.2 (Gene Codes Corporation, Ann Arbor, MI, USA). All the sequences were aligned using the multiple sequence comparison alignment tool in MAFFT v6 [23]. Sequences of AMF DNA from C. edulis roots were compared with the existing sequences in the National Centre for Biotechnology Information (NCBI) by BLAST. CLUSTAL MEGA was used to perform multiple sequence alignment (MSA), after which phylogenetic tree was generated using MEGA X [24] by maximum likelihood method and Tamura-Nei model [25].

\section{Results}

3.1. AMF Spore Count. Overall, preliminary AMF spore count in soil samples from all the sampling sites had significantly $(P<0.05)$ lower number of spore count recording an average $(41 \%)$ compared to the number of spores after bulking (59\%).

Both soil sample spore count before and after bulking showed that Homa Bay sampling area had the highest number of spores with a mean count of 105 before bulking and 148 after bulking per $50 \mathrm{~g}$ of soil sample. This was followed by Kisumu at 101 spores before bulking and 144 after bulking while Siaya recorded 100 spores before bulking and 142 after bulking (Figure 2). Varying depths for soil sample collection were considered to find out which layer of the soil had more spores. In all the sites, the depth of $0-15 \mathrm{~cm}$ had the highest numbers of spores with the mean count of 52.58 before bulking and 78.94 after bulking compared to the $15-30 \mathrm{~cm}$ depth that had mean counts of 49.19 before bulking and 65.42 after bulking (Table 2).

Root percentage infection was also done and overall mean of $55.42 \%$ was recorded. Kisumu had the highest mean of $58.67 \%$ followed by Homa Bay (54\%) while Siaya site recorded the least percentage infection of 50.85 .

3.2. Morphological Analysis of AMF. The roots of C. edulis from all the six sampling sites that were examined under fluorescent microscope revealed typical structures of AMF infection with arbuscules and vesicles confirming the association between the plant and AMF (Figure 3). Vesicles tend to take the shape of the plant cell while arbuscules appear like round structures in the roots. Both arbuscules and vesicles picked trypan deep blue colour as observed under a fluorescent microscope.

In the soil samples, the study found that some spores appeared singly or in aggregates in an unorganized hyphal matrix with the layers of the spore wall appearing continuous with the wall of subtending hypha. These spores were borne terminally and ranged within 90-400 $\mu \mathrm{m}$ in diameter with varying colours. Some spores were yellow and others were dark brown while others were light brown fitting the description of AMF of genera Glomus. Six hundred and sixty-nine (669) of the spores that fit this description were found in Homa Bay, and 739 were found in Kisumu while 815 were found in Siaya. Another group of spores appeared on or within the neck (subtending hypha) of a sporiferous saccule with yellowish and light brown colouration and the size ranged within $140-260 \mu \mathrm{m}$ in diameter. This group fits Acaulospora AMF genera. Two hundred and sixty-five (265) were found in Homa Bay, 312 in Kisumu, and 281 in Siaya. The study also found another group of spores that were 


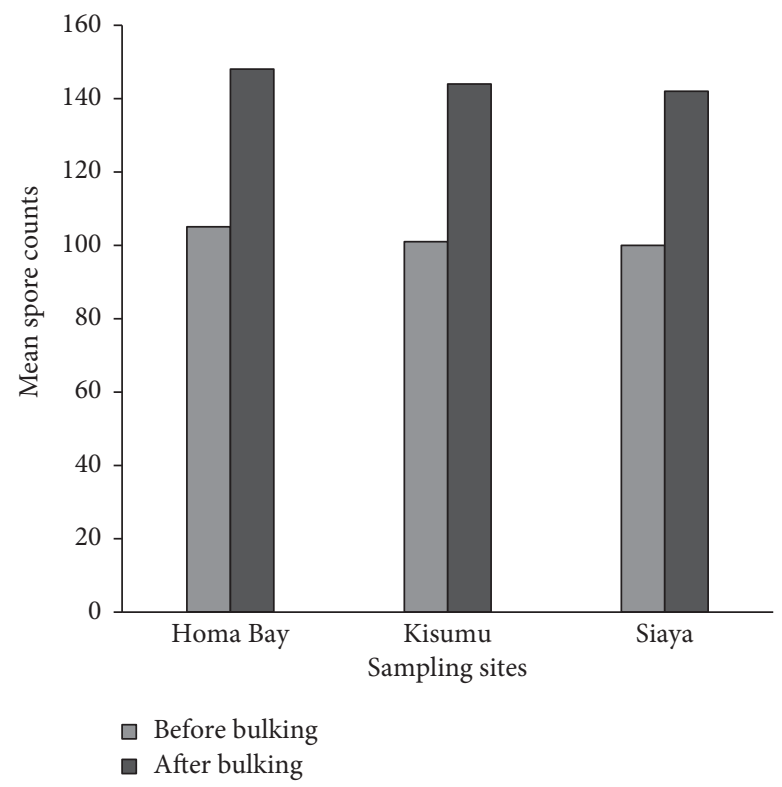

Figure 2: Mean number of AMF spores per $50 \mathrm{~g}$ of soil sample from the sampling sites.

TABle 2: The mean spore count in varying depths from different sampling sites before and after bulking.

\begin{tabular}{|c|c|c|c|c|}
\hline \multirow{2}{*}{ Sampling area } & \multicolumn{2}{|c|}{ Mean no. of spores before bulking } & \multicolumn{2}{|c|}{ Mean no. of spores after bulking } \\
\hline & $0-15 \mathrm{~cm}$ depth & $15-30 \mathrm{~cm}$ depth & $0-15 \mathrm{~cm}$ depth & $15-30 \mathrm{~cm}$ depth \\
\hline Kisumu & 50.17 & 50.25 & 79.5 & 64.17 \\
\hline Homa Bay & 56.73 & 48 & 79.27 & 67.82 \\
\hline Siaya & 51.31 & 49.23 & 78.15 & 64.54 \\
\hline Total & 52.58 & 49.19 & 78.94 & 65.42 \\
\hline
\end{tabular}

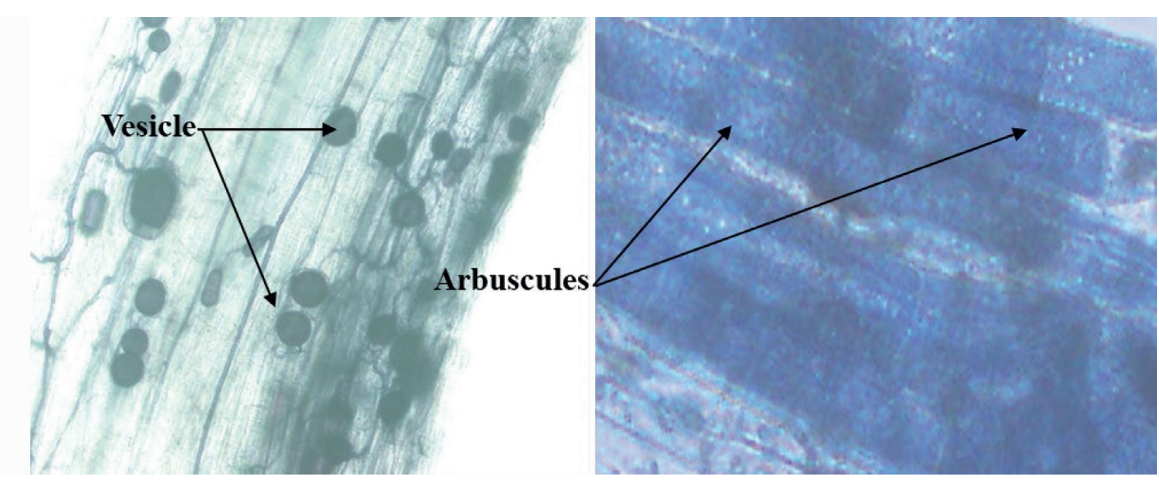

FIGURE 3: Carissa edulis roots that are infected with AMF showing vesicles and arbuscules within the root under $\times 50$ fluorescent microscope.

bilayered, thin wall auxiliary cells with smooth surfaces produced on hypha. These spores also had small bulb on the subtending hyphae. The size ranged within 100-260 $\mu \mathrm{m}$ with yellowish, light brown, and dark brown colouration. These characteristics were found to match those of Scutellospora. Five hundred and forty-eight (548) of these spores were found in Homa Bay, 579 in Kisumu, and 605 in Siaya. Yet another group of spores appeared to be bilayered and had small bulb on the subtending hyphae, and spores had no ornamentations. These spore sizes ranged within
$250-360 \mu \mathrm{m}$ with a greenish yellow colouration. These features fit those of a Gigaspora. One hundred and three (103) of these spores were found in Homa Bay, 134 in Kisumu, and 151 in Siaya.

The spores were counted per $50 \mathrm{~g}$ of soil sample and were found to belong to four genera of AMF: Gigaspora, Acaulospora, Scutellospora, and Glomus. These genera were identified using morphological characteristics of the spores according to INVAM (http://invam.caf.wvu.edu/). Glomus was the most abundant of all the AMF with the mean spore 
count of 61.31 followed by Scutellospora (47.67), Acaulospora (23.56), and Gigaspora (11.06) (Table 3).

The AMF spores were characterized according to their shapes, sizes, colour, and the presence of subtending hyphae (Figure 4) after bulking. In terms of shape, the majority of spores appeared either spherical or oval. The spherical spores were the highest with the mean spore count of 71.33 while oval ones had mean spore count of 62.58 .

In terms of size, there were more large spores recording mean count of 70 than small spores at 62.11. During the characterization, some spores appeared yellow, dark brown, and dark while others light brown with mean counts of $40.89,37.47,31.81$, and 21.36 , respectively. The presence of subtending hyphae was also considered and the majority of the spores counted at the time of examination were lacking the subtending hyphae (mean count of 80.75) compared to spores that had the subtending hyphae at 49.97.

3.3. Molecular Analysis of AMF. Molecular analysis of partial small subunit rDNA from the roots of $C$. edulis using nested PCR yielded the expected results of 1100 bp by NS1 and NS4 primer pairs and 800 bp by AML1 and AML2 primer pairs according to [16].

Four different restriction enzymes, HaeIII, MpsI, Hinfl, and HhaI were used in restriction fragment length polymorphism (RFLP) and revealed molecular diversity (Supplementary Figures 1 and 2). They generated different bands of different sizes against the $100 \mathrm{bp}$ molecular marker. HaeIII generated two prominent sets of bands for AMF. One set generated at $900 \mathrm{bp}$ while another set was generated at $350 \mathrm{bp}$. Hha generated two bands in some samples and three bands in others at $700 \mathrm{bp}, 400 \mathrm{bp}$, and $300 \mathrm{bp}$. In Hinfl enzyme, some bands were generated in some samples at $600 \mathrm{bp}, 500 \mathrm{bp}$, and $400 \mathrm{bp}$ and MspI generated fewer bands of all the four restriction enzymes at $800 \mathrm{bp}$ and $400 \mathrm{bp}$. It was not easy to tell which of the four enzymes was the most effective because each enzyme generated different bands per sample. The bands were assumed to represent different AMF species.

The bands generated by RFLP could not reveal the species or genera of the AMF isolated; therefore, AMF DNA sequencing was performed. Nineteen AMF DNA amplicons that generated clear bands were selected and sequenced. The sequences were phylogenetically analyzed. The obtained phylogenetic tree (Figure 5) generated 14 species. These include seven, three, two, and 1 species of Glomus, Acaulospora, uncultured Glomeromycotina, and uncultured Rhizophagus, respectively. Sequencing of AMF DNA revealed that Glomus was the predominant genera infecting the roots of C. edulis plant within Lake Victoria ecosystem. Even though Kisumu area seems to be having larger number of Glomus, the distribution of the genus is fairly uniform across the region. Acaulospora was evenly distributed across the three sampling sites though slightly high in Homa Bay. The distribution of the uncultured Glomeromycotina clone was also uniformly distributed across the region. Uncultured Rhizophagus was only found in one sampling site in Siaya area. DNA sequencing did not reveal anything on
TABLE 3: Mean spore count of AMF genera in the sampling areas.

\begin{tabular}{lcccc}
\hline \multirow{2}{*}{ Sampling site } & \multicolumn{4}{c}{ Number of spores per genus } \\
& Gigaspora & Acaulospora & Scutellospora & Glomus \\
\hline Kisumu & 10.67 & 26.25 & 44.75 & 60.42 \\
Homa Bay & 10.64 & 22.91 & 51.45 & 61.18 \\
Siaya & 11.77 & 21.62 & 47.15 & 62.23 \\
Total & 11.06 & 23.56 & 47.67 & 61.31 \\
\hline
\end{tabular}

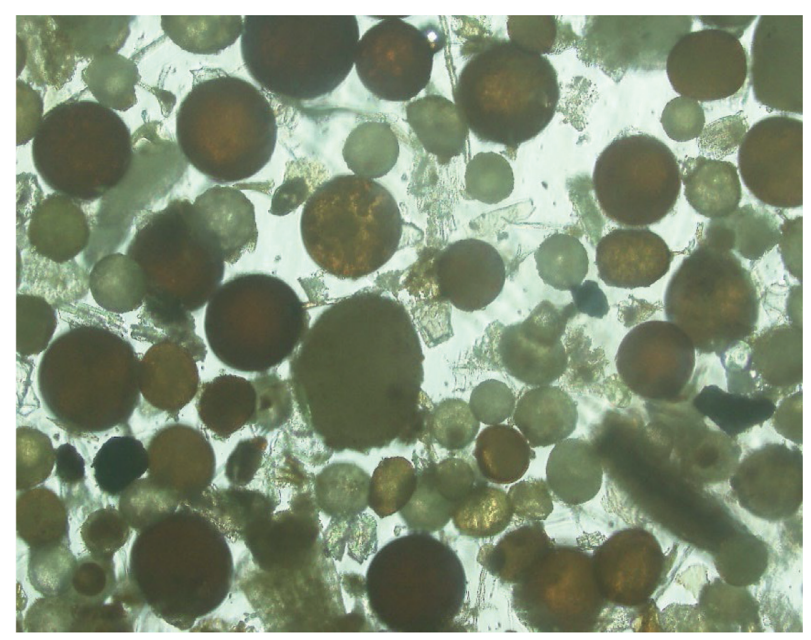

FIgURE 4: Micrographs of spores observed under $\times 50$ florescent microscope showing different shapes, colours, and subtending hyphae.

Scutellospora and Gigaspora as did in morphological characterization while it discovered a species of Rhizophagus that was not identified during the morphological analysis.

\section{Discussions}

Mycorrhizae symbiosis is a key component in helping plants cope with adverse environmental conditions through regulation of their growth and development $[26,27]$ and had been reported about 400 million years ago [28]. As reported by Smith and Read [29], AMF have mutualistic relationships with more than $80 \%$ of terrestrial plant species and the present study shows that AMF successfully develops symbiotic mycorrhizae with C. edulis within the study area.

The main aim for setting up pot trap culture (bulking) using Sorghum bicolor in this study was to propagate AMF spores in good numbers for clearer microscopic analysis and morphological characterization. As described in [30], the procedure is widely used in AMF ecological studies and usually provides sufficient quantities of viable spores with almost all morphological traits that can aid accurate identification and detection of nonsporulating AMF species. A similar strategy has been used in other studies [31] and led to $18 \%$ increase in spore count after bulking compared to the preliminary spore count. Besides increased sporulation of AMF in trap cultures, some studies have shown species richness after bulking [32]; however, in the present study, no increase in species richness was observed, similar to what was reported in [33]. 


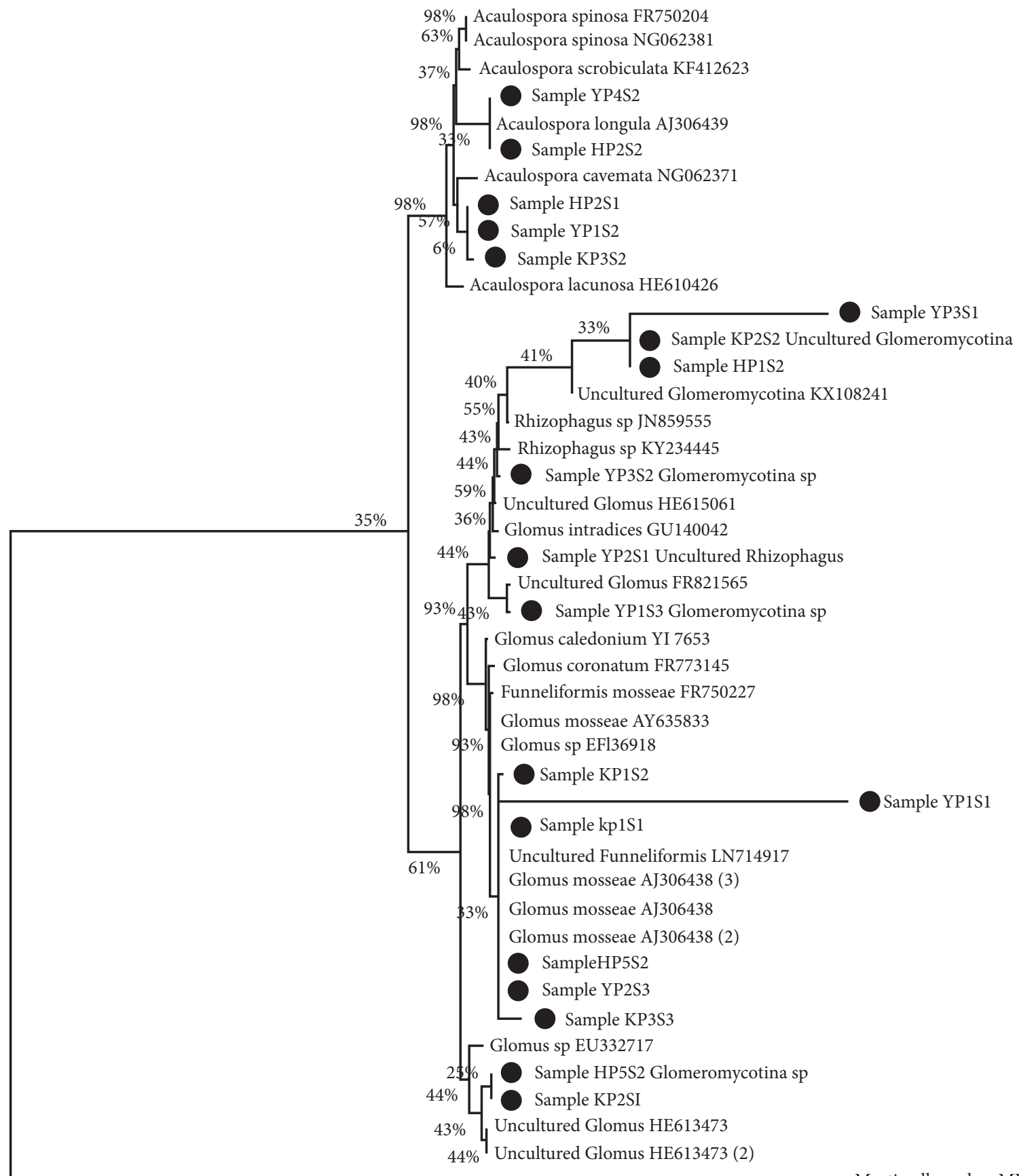

Mortierella zychae MH857054

0.10

FIGURE 5: Phylogenetic tree generated using MEGA X by maximum likelihood method and Tamura-Nei model showing sequences of SSU rDNA of AMF from C. edulis roots (in bold type).

Morphological assessment (spore size, colour) of AMF spores from soil samples collected under C. edulis plants suggested the presence of four genera (Gigaspora, Acaulospora, Scutellospora, and Glomus) with variations within the genera. We found that the size of Glomus spores ranged within $90-400 \mu \mathrm{m}$ with varying colours: yellow, dark brown, and light brown. Acaulospora ranged within $140-260 \mu \mathrm{m}$ in diameter with yellowish and light brown colouration.
Scutellospora had its spore diameter ranging from 100 to $260 \mu \mathrm{m}$ with yellowish, light brown, and dark brown colouration while Gigaspora recoded spores with diameter ranging from 250 to $360 \mu \mathrm{m}$ with greenish yellow colouration. Such diversity may reflect the ability to survive or functionality of the species [34]. It was not within the scope of this study to determine exactly what causes variations in the colour and the size of the AMF spores of the same 
species; however, soil chemistry was suspected to play a key role in the diversity observed. Koch et al. [35] reported similar variations; however, more genetic diversity studies should be conducted within or among AMF species for better understanding of their functional roles in these ecosystems. Another study by [36] found that elevated temperatures reduced the AMF spore diameter by almost $10 \%$ indicating that environmental condition could be playing a role in spore size variation. However, [37] found that it was not easy to classify AMF species based on the spore size because of great spore size overlap among AMF species. A similar result was reported in the woodlands of Northern Ethiopia by [38]. The sampling sites in the present study are generally known for rampant livestock grazing, which may have had an impact on the species richness; however, this was not examined. Furthermore, AMF belonging to the Glomus genus are known to be tolerant if not resistant to soil and ecosystem disturbances [39].

The percentage of $C$. edulis root colonization obtained in this study $(54.42 \%)$ was comparatively high and similar to those reported by other workers such as [21] for Jatropha curcas in Guantánamo, Cuba and [22] for the same species in Viçosa, Brazil. These findings suggest that terrestrial plants majorly rely on mycorrhizal symbiosis and percentage infection with AMF of about $50 \%$ to $60 \%$ is enough to thrive the plants in diverse climatic conditions [40]. Among the four genera identified in the present study, Glomus was the most abundant AMF infecting roots of $C$. edulis within the Lake Victoria ecosystem probably because it is generally sporageous and resilient to disturbance. This finding corroborates the earlier reports suggesting that Glomus is the major AMF genera infecting the roots of most terrestrial plants across the world [41]. Probably, high adaptability of this genus to the variations of temperature and soils characteristics could explain its abundance. In addition, its ability to survive in wider soil $\mathrm{pH}$ range and resilience to soil disturbances may be making Glomus dominant among terrestrial plants [42]. In addition, works by [43] suggested that the difference in development process might also explain the reason why Acaulospora and Glomus species dominate roots of most terrestrial plants. This is because they require less time to produce spores than Gigaspora and Scutellospora species. Members of Gigasporaceae typically establish an extensive mycelium in soil and produce fewer spores than those of Acaulosporaceae and Glomaceae. The authors in [38, 44] established that Glomus and Acaulospora are resistant to soil disturbances and changes in ecosystem. This makes Glomus a good alternative for production of inoculum to be used even in the period of formation of plant seedlings including those of $C$. edulis.

The variation in AMF spore abundance among the sites could not be attributed to any factor and only viewed as a mere chance even though it was suspected that the existence of Rhus natalensis in close proximity with C. edulis had something to do with the large number of spores in some areas. This is an argument that requires further investigation. In general, AMF spore densities are affected by soil erosion and mechanical disturbance due to livestock grazing [38]. In the same way, [44] found that soil disturbance reduces AM fungi spore densities; particularly AM fungi Entrophospora is sensitive to human disturbance and soil erosion.

Our study found that the uppermost soil horizon (depth of $0-15 \mathrm{~cm}$ ) had more spores than that of deeper soil horizon $(15-30 \mathrm{~cm})$. This was attributed to the fact that C. edulis just like many other plants has both tap and lateral roots and the fine roots projecting from lateral roots tend to spread just beneath the earth surface that fall within $0-15 \mathrm{~cm}$ where interaction between the roots and AMF spores occurs most. This was not far from the findings reported by Ezeokoli et al. [45] where they collected soil samples randomly at depths of $\leq 20 \mathrm{~cm}$ (topsoil) and $>20 \mathrm{~cm}$ (subsoil) for AMF spore density assessment and found that topsoil of $\leq 20 \mathrm{~cm}$ had higher number of spores than the subsoil. Our findings also concur with those of [46] showing that the function of AMF in efficient and intensive extraction of soluble nutrients is concentrated in the uppermost soil horizon where organic matter is found and most root growth occurs. This also explains why disturbance of soil especially by grazing livestock would reduce the spore density according to [44].

Restriction fragment length polymorphism (RFLP) analysis revealed the presence of genetic diversity for AMF within the samples collected. However, the restriction by the enzymes could not categorically determine the genus and species of the AMF; therefore DNA sequencing was done to help to assign samples to a genus or a species group. Molecular analysis through sequencing just like morphological analysis revealed that Glomus was the predominant AMF genera sporulating with C. edulis; however, there was inconsistency between molecular and morphological analyses in that only Glomus and Acaulospora were common in both analyses. In molecular analysis, besides Glomus and Acaulospora, uncultured Glomeromycotina, and uncultured Rhizophagus were also identified while in the morphological analysis Scutellospora and Gigaspora were reported. The primers AML1 and AML2 allow robust amplification of AMF sequences directly from field roots, comparable to that obtained with the widely used NS31-AM1 combination [47]. From phylogenetic analysis, all the sequences fell within the phylum Glomeromycota. Lee et al. [47] found that AML1 and AML2 primer pairs had much better specificity and coverage of all known AMF groups. Owing to better specificity of the primer pairs, Gigaspora and Scutellospora as revealed by morphological analysis in this study would have been picked and amplified. Therefore, to miss the two genera by AML1 and AML2 could mean they were sporulating with other plants within the proximity other than the target plant. Ćatská et al. [48] also found dissimilar results between molecular and morphological analyses and attributed it to the reduced number of spores of some species found in the field or the dilution of spore in the sample preparation. The gene SSU rDNA that was amplified in this study had been studied to develop PCR-based methodology to determine the presence of AMF in soil and roots using the same set of primers in [49] of Cardiospermum halicacabum L. and Ricinus communis L. This gene evolves relatively slow and may not provide sufficient information to adequately characterize the AMF guild within a community. A more appropriate approach could rely on the sequence variability 
of the internal transcribed spacer regions (ITS) between the small and large subunits of the rRNA genes [50, 51].

\section{Conclusion}

In conclusion, we have assessed for the first time within Lake Victoria ecosystem the diversity of mycorrhizal fungi in the soil and roots of $C$. edulis. A wide variety of arbuscular mycorrhizal spores were identified in the rhizosphere of this plant by morphological investigations, while the microscopic observations of intraradicular hyphae indicated a high colonization rate of $C$. edulis. The results obtained in this study constitute a solid scientific basis and another pathway to preserve and maybe to enhance restoration of C. edulis populations within the region.

\section{Data Availability}

Data are available on request from the authors.

\section{Conflicts of Interest}

The authors declare that they have no conflicts of interest.

\section{Acknowledgments}

The authors would like to thank Kenya Forestry Research Institute (KEFRI) for technical support and the entire molecular laboratory staff at KEFRI for the facility. They also appreciate Prof. Wallace Bulimo of University of Nairobi and the head of Walter Reed Project (WRP) Influenza Reference Laboratory, Nairobi, together with his staff for offering the DNA sequencing facilities.

\section{Supplementary Materials}

Supplementary data consists of electropherograms of PCR products of the target gene area and the patterns of restricted fragments of the PCR products after digestion with restriction enzymes. Figure S1: agarose gel showing PCR products from 1 to 21 while $\mathrm{M}$ in both ends represent $100 \mathrm{bp}$ marker. Figure S2: example of a HaeIII restriction fragment length polymorphism (RFLP) electropherogram. (Supplementary Materials)

\section{References}

[1] P. Maundu, G. W. Ngug, and C. S. Kabuye, Traditional Food Plants of Kenya: Kenya Resource Centre for Indigenous Knowledge, National Museums of Kenya, Nairobi, Kenya, 1999.

[2] T. Mutshinyalo and R. Malatji, Carissa Edulis Vahl, South Africa National Biodiversity Institute, Pretoria, South Africa, 2012.

[3] M. Tolo, M. Rukunga, W. Muli et al., "Antiviral activity of the extracts of a Kenyan herpes simplex virus," Journal of Ethnopharmacology, vol. 104, pp. 92-99, 2006.

[4] L. M. Egerton-Warburton, J. I. Querejeta, M. F. Allen, and S. L. Finkelman, "Mycorrhizal fungi," Reference Module in Earth Systems and Environmental Sciences, Elsevier, Amsterdam, Netherlands, 2013.
[5] J. C. Tarafdar and H. Marschner, "Phosphatase activity in the rhizosphere and hyphosphere of VA mycorrhizal wheat supplied with inorganic and organic phosphorus," Soil Biology and Biochemistry, vol. 26, no. 3, pp. 387-395, 1994.

[6] M. Ducousso, H. Ramanankierana, R. Duponnois et al., "Mycorrhizal status of native trees and shrubs from eastern madagascar littoral forests with special emphasis on one new ectomycorrhizal endemic family, the asteropeiaceae," New Phytologist, vol. 178, no. 2, pp. 233-238, 2008.

[7] B. Bago, P. E. Pfeffer, and Y. Shachar-Hill, "Carbon metabolism and transport in arbuscular mycorrhizas," Plant Physiology, vol. 124, no. 3, pp. 949-958, 2000.

[8] H. Enom, C. Hartnett, and T. Wilson, "Host plant species effects on arbuscular mycorrhizal fungal communities in tall grass prairie," Oecologia, vol. 122, pp. 435-444, 2000.

[9] N. Klironomos, J. McCune, M. Hart, and J. Neville, "The influence of arbuscular mycorrhizae on the relationship between plant diversity and productivity," Ecology Letters, vol. 3, pp. 137-141, 2000.

[10] M. Mills and D. Bever, "Maitenance of diversity within plant communities: soil pathogens as agents of feedback," Ecology, vol. 79, pp. 1595-1601, 1998.

[11] J. W. Gerdemann and T. H. Nicolson, "Spores of mycorrhizal endogone species extracted from soil by wet sieving and decanting," Transactions of the British Mycological Society, vol. 46, no. 2, pp. 235-244, 1963.

[12] D. Redecker, A. Schüßler, H. Stockinger, S. L. Stürmer, J. B. Morton, and C. Walker, "An evidence-based consensus for the classification of arbuscular mycorrhizal fungi (glomeromycota)," Mycorrhiza, vol. 23, pp. 515-531, 2013.

[13] J. M. Phillips and D. S. Hayman, "Improved procedures for clearing roots and staining parasitic and vesicular arbuscular mycorrhizal fungi for rapid assessment of infection," Transaction British Mycological Society, vol. 55, pp. 158-161, 1970.

[14] M. Giovannetti and B. Mosse, "An evaluation of techniques for measuring vesicular arbuscular mycorrhizal infection in roots," New Phytologist, vol. 84, no. 3, pp. 489-500, 1980.

[15] S. Isshiki, A. Togayachi, T. Kudo et al., "Cloning, expression, and characterization of a novel UDP-galactose: $\beta$-N-acetylglucosamine $\beta 1$, 3-galactosyltransferase ( $\beta 3 \mathrm{Gal}-\mathrm{T} 5)$ responsible for synthesis of type 1 chain in colorectal and pancreatic epithelia and tumor cells derived therefrom," Journal of Biological Chemistry, vol. 274, no. 18, pp. 12499-12507, 1999.

[16] G. Casazza, E. Lumini, E. Ercole et al., "The abundance and diversity of arbuscular mycorrhizal fungi are linked to the soil chemistry of screes and to slope in the alpic paleo-endemic Berardia subacaulis," PLoS One, vol. 12, no. 2, Article ID e0171866, 2017.

[17] T. J. White, T. Bruns, S. J. W. T. Lee, and J. Taylor, “Amplification and direct sequencing of fungal ribosomal RNA genes for phylogenetics," PCR protocols: A Guide to Methods and Applications, vol. 18, no. 1, pp. 315-322, 1990.

[18] H. Lee, C. Yuan, A. Hammet et al., "Diphosphothreoninespecific interaction between an SQ/TQ cluster and an FHA domain in the Rad53-Dun1 kinase cascade," Mol Cell, vol. 30, no. 6, pp. 767-778, 2008.

[19] M. W. McDonell, M. N. Simon, and F. W. Studier, "Analysis of restriction fragments of T7 DNA and determination of molecular weights by electrophoresis in neutral and alkaline gels," Journal of Molecular Biology, vol. 110, pp. 119-146, 1977.

[20] E. Southern, "Gel electrophoresis of restriction fragments," Methods in Enzymology, vol. 68, pp. 152-176, 1979.

[21] M. d. M. Alguacil, E. Torrecillas, G. Hernández, and A. Roldán, "Changes in the diversity of soil arbuscular 
mycorrhizal fungi after cultivation for biofuel production in a guantanamo (Cuba) tropical system," PLoS One, vol. 7, no. 4, Article ID e34887, 2012.

[22] B. C. Moreira, A. L. Rodrigues, S. F. Oliveira et al., "Arbuscular mycorrhizal fungi in the jatropha curcas rhizosphere," African Journal of Microbiology Research, vol. 9, no. 15, pp. 1060-1074, 2015.

[23] K. Katoh and H. Toh, "Recent developments in the MAFFT multiple sequence alignment program," Brief Bioinform, vol. 9, no. 4, pp. 286-298, 2008.

[24] S. Kumar, G. Stecher, M. Li, C. Knyaz, and K. Tamura, "Mega $\mathrm{X}$ : molecular evolutionary genetics analysis across computing platforms," Molecular Biology and Evolution, vol. 35, pp. 1547-1549, 2018.

[25] K. Tamura and M. Nei, "Estimation of the number of nucleotide substitutions in the control region of mitochondrial DNA in humans and chimpanzees," Molecular Biology and Evolution, vol. 10, pp. 512-526, 1993.

[26] J. M. Ruiz-Lozano and R. Azcón, "Symbiotic efficiency and infectivity of an autochthonous arbuscular mycorrhizal glomus sp. from saline soils and glomus deserticola under salinity," Mycorrhiza, vol. 10, no. 3, pp. 137-143, 2000.

[27] Z. Song, Y. Bi, J. Zhang, Y. Gong, and H. Yang, "Arbuscular mycorrhizal fungi promote the growth of plants in the mining associated clay," Scientific Reports, vol. 10, pp. 1-9, 2020.

[28] M. A. Selosse, C. Strullu-Derrien, F. M. Martin, S. Kamoun, and P. Kenrick, "Plants, fungi and oomycetes: a 400-million years affair that shapes the biosphere," New Phytologist, vol. 206, pp. 501-506, 2015.

[29] S. Smith and D. Read, Mycorrhiza Symbiosis, Academic Press, San Diego, CA, USA, 3rd edition, 2008.

[30] P. L. Leal, T. S. DE Carvalho, J. O. Siqueira, and F. M. S. Moreira, "Assessment of the occurrence and richness of arbuscular mycorrhizal fungal spores by direct analysis of field samples and trap culture-a comparative study," Annals of the Brazilian Academy of Sciences, vol. 90, no. 2, pp. 2359-2373, 2018.

[31] G. Selvakumar, C. C. Shagol, Y. Kang, B. N. Chung, S. G. Han, and T. M. Sa, "Arbuscular mycorrhizal fungi spore propagation using single spore as starter inoculum and a plant host," Journal of Applied Microbiology, vol. 124, no. 6, pp. 1556-1565, 2018.

[32] S. Friberg, "Distribution and diversity of arbuscular mycorrhizal fungi in traditional agriculture on the Niger inland delta, Mali, west Africa," Colorado Business Magazine: S Skriftserie, vol. 3, pp. 53-80, 2001.

[33] F. Oehl, E. Sieverding, K. Ineichen, P. Mader, T. Boiler, and A. Wiemken, "Impact of land use intensity on the species diversity of arbuscular mycorrhizal fungi in agroecosystems of central Europe," Applied and Environmental Microbiology, vol. 69, pp. 2816-2824, 2003.

[34] A. Colard, C. Angelard, and I. R. Sanders, "Genetic exchange in an arbuscular mycorrhizal fungus results in increased rice growth and altered mycorrhiza-specific gene transcription," Applied and Environmental Microbiology, vol. 77, no. 18, pp. 6510-6515, 2011.

[35] A. M. Koch, D. C. Ian, and R. Sanders, "Genetic variability in a population of arbuscularmycorrhizal fungi causes variation in plant growth," Ecology Letters, vol. 9, pp. 103-110, 2006.

[36] T. Zhang, X. Yang, R. Guo, and J. Guo, "Response of AM fungi spore population to elevated temperature and nitrogen addition and their influence on the plant community composition and productivity," Scientific Reports, vol. 6, no. 1, pp. 1-12, 2016.
[37] N. C. Schenck and Y. Perez, Manual for the Identification of VA Mycorrhizal Fungi, Vol. 286, Synergistic Publications, Gainesville, FL, USA, 1990.

[38] M. Welemariam, F. Kebede, B. Bedadi, and E. Birhane, "Exclosures backed up with community-based soil and water conservation practices increased soil organic carbon stock and microbial biomass carbon distribution, in the northern highlands of Ethiopia," Chemical and Biological Technologies in Agriculture, vol. 5, no. 1, pp. 1-11, 2018.

[39] C. Maciel, R. Pereira, D. Karla et al., "Diversity of arbuscular mycorrhizal fungi in Atlantic forest areas under different land uses," Agriculture, Ecosystems \& Environment, vol. 185, pp. 245-252, 2014.

[40] N. Diagne, M. Ngom, P. I. Djighaly, D. Fall, V. Hocher, and S. Svistoonoff, "Roles of arbuscular mycorrhizal fungi on plant growth and performance: importance in biotic and abiotic stressed regulation," Diversity, vol. 12, no. 10, p. 370, 2020.

[41] R. Husband, E. A. Herre, S. L. Turner, R. Gallery, and J. P. W. Young, "Molecular diversity of arbuscular mycorrhizal fungi and patterns of host association over time and space in a tropical forest," Molecular Ecology, vol. 11, no. 12, pp. 2669-2678, 2002.

[42] A. Becerra, N. Bartoloni, N. Cofré, F. Soteras, and M. Cabello, "Arbuscular mycorrhizal fungi in saline soils: vertical distribution at different soil depth," Brazilian Journal of Microbiology, vol. 45, no. 2, pp. 585-594, 2014.

[43] M. Wang and P. Jiang, "Colonization and diversity of AM fungi by morphological analysis on medicinal plants in southeast China," The Scientific World Journal, vol. 2015, Article ID 753842, 7 pages, 2015.

[44] D. Muleta, F. Assefa, S. Nemomissa, and U. Granhall, "Distribution of arbuscular mycorrhizal fungi spores in soils of smallholder agroforestry and monocultural coffee systems in southwestern Ethiopia," Biology and Fertility of Soils, vol. 44, no. 4, pp. 653-659, 2008.

[45] O. T. Ezeokoli, S. K. Mashigo, M. S. Maboeta, C. C. Bezuidenhout, D. P. Khasa, and R. A. Adeleke, "Arbuscular mycorrhizal fungal community differentiation along a post-coal mining reclamation chronosequence in South Africa: a potential indicator of ecosystem recovery," Applied Soil Ecology, vol. 147, Article ID 103429, 2019.

[46] E. Sieverding, J. Friedrichsen, and W. Suden, VesicularArbuscular Mycorrhiza Management in Tropical Agrosystems, Sonderpublikation der GTZ (Germany), Berlin, Germany, 1991.

[47] J. Lee, S. Lee, and J. P. W. Young, "Improved PCR primers for the detection and identification of arbuscular mycorrhizal fungi," FEMS Microbiology Ecology, vol. 65, no. 2, pp. 339-349, 2008.

[48] V. Čatská, S. E. Smith, and D. J. Read, "Mycorrhizal symbiosis," Biologia Plantarum, vol. 40, no. 1, p. 154, 1997.

[49] J. P. Clapp, A. H. Fitter, and J. P. W. Young, "Ribosomal small subunit sequence variation within spores of an arbuscular mycorrhizal fungus, scutellospora sp," Molecular Ecology, vol. 8, no. 6, pp. 915-921, 1999.

[50] D. Redecker, "Specific PCR primers to identify arbuscular mycorrhizal fungi within colonized roots," Mycorrhiza, vol. 10, no. 2, pp. 73-80, 2000.

[51] I. R. Sanders, M. Alt, K. Groppe, T. Boller, and A. Wiemken, "Identification of ribosomal DNA polymorphisms among and within spores of the glomales: application to studies on the genetic diversity of arbuscular mycorrhizal fungal communities," New Phytologist, vol. 130, no. 3, pp. 419-427, 1995. 